\title{
CODIFICATION OF THE SPOKEN LANGUAGE: AN EXAMPLE OF CONTEMPORARY SLOVENE
}

\section{INTRODUCTION}

Since its inception, the first books by Slovene Protestants in the $16^{\text {th }}$ century (Primož Trubar, Jurij Dalmatin and others), the Standard Slovene language has played an important role in the forming of the Slovene nation. ${ }^{1}$ Thus the Bible by Dalmatin (1584) was actually also a supra-regional Bible, used by Protestants and Catholics alike. A return to the standard language of the Slovene Protestants was seen also in the $19^{\text {th }}$ century, when the Slovene language began to be used more extensively in public. Since the second half of the $19^{\text {th }}$ century, beginning with the so-called "Spring of the Nations" in 1848, the language and its public use and manifestation became a very important factor in the creation of the Slovene nation. An important function of the literary language was its ability to unify and reach every Slovene, with only the origin of its speakers regionally defined. This supra-regional element, retained today as the Standard language used by the media and elsewhere, demonstrates a continued degree of linguistic unity throughout Slovenia.

\section{THE FORMING OF SLOVENE ORTHOEPY}

Orthoepy is a "linguistic branch that searches for, and establishes, the best regular way to pronounce phonemes and their prosodic properties, which is the pronunciation (= reading) of both" (Toporišič 1992: 205). ${ }^{2}$ Orthoepy had already begun to be established with the first written records and codification, a "literary" transformation of languages, which brought about discussion on the appropriateness of these first records, or the pronunciation of an individual written language. The origin of these discussions reaches back to Panini, in the $4^{\text {th }}$ century B.C. In truth, the relationship between the written and the spoken word began with the first written records in the

\footnotetext{
*Author's address: Filozofska fakulteta, Oddelek za slovenistiko, Aškerčeva 2, 1000 Ljubljana. Email: hotimir.tivadar@ff.uni-lj.si

${ }^{1}$ In local linguistic terminology, the term Slovenski knjižni jezik commonly refers to the written language, and is sometimes translated as "Slovene literary language." The concept of a literary language is often joined with the term govorjeni knjižni jezik, meaning a "spoken literary Slovene," since its structural properties are seen as being based on the written language. In this paper, Standard Slovene language is used to refer to the so-called written Standard Slovene language, while Standard Spoken Slovene, or govorjeni knjižni jezik, stands for the spoken standard Slovene language.

2 Orthoepy may also be defined as a book of written rules that, along with orthoepic norms, warn against certain pronunciations and other orthoepic problems (Toporišič 1992: 205).
} 
Middle East (circa 1500 B.C.), also "the old faith in India... even demanded phonetic precision in written prayers, or else they will not be answered" (Čar 1995: 45).

Codification, and thus orthoepy, began to develop along with the printed word, and the appearance of printed books that were readily available to a wider public. At first, these records had a predominantly religious, liturgical character (even Evangelical), therefore they had to be comprehensible to a wide circle of addressees. Because of this, the use of the Standard Slovene language as a unifying element for the Slovene nation and the Protestant church (that Primož Trubar attempted to establish with his Cerkovna ordninga of 1564), ${ }^{3}$ was entirely topical. However, at the time, in the middle of the $16^{\text {th }}$ century, we can hardly speak of a well-formed Standard Slovene language, much less of a well-formed Spoken Standard language. ${ }^{4}$ Furthermore, Ljubljana was still trying to assert itself as an economic, political, and cultural centre, whilst the large Slovene centres of Trieste and Celovec (Klagenfurt) had great influence. The Slovene language was mostly confined to a private, and chiefly unofficial, use. Therefore, we can position the true beginnings of the Slovene orthoepy and the formation of the Spoken Standard language to the period after 1848, when the Slovene language was acknowledged as one of the equal provincial languages within the Austro-Hungarian Monarchy. During that period, through the introduction of new forms, the written standard was established (Jesenšek 2010). These new-Carinthian-Styrian forms were to be the bridge that "ties us to Illyrians and other Slavic people, to whom our audience was leaning at the time" (Breznik 1982: 87). ${ }^{5}$

These unifying new forms were introduced in a Pan-Slavic and, consequently, in a Pan-Slovene sense.

In the second half of the $19^{\text {th }}$ century, the Slovene language asserted itself in schools, in publications (for example, in the journal Novice), and in literature, among other spheres of public life. The unformed spoken norm of the written language, and

${ }^{3}$ Cerkovna ordninga (1564) is a Slovene book about the Protestant doctrine and the church order, which was the first religious text of Protestants in the Austrian provinces.

4 "Kadar ta Slovenski Jezik se povsod glihinu veni viži ne govori, drigazhi govore zdostimi besedami Krajnci, drigači Korošci, drigači Štajerji inu Dolenci tar Bezjaki, drigači Krašovci inu Istriani, drigači Crouati" (Trubar 1555 in: Gjurin/Toporišič 1993: 422). ("The Slovene language is not spoken in the same way around the land, different words and expressions are used by Carniolans, Carinthians, Styrians, Lower Carniolans, "Bezjakis," "Krašovcis" and Istrians, and are different again with Croats," translated by L. Ličar.) Trubar was already aware of the variety present in the Slovene language and, as is written in the continuation of this preface on the written and spoken word, took as a basis for the written language the "Carniolan" language, which could be considered a central language, easily understood by everyone.

${ }^{5}$ Supporters of the new forms and supporters of Svetec included Navratil, Levstik, Miklošič, Cegnar and Cigale, who in 1860 prepared the Slovene State Code and already introduced into it the new forms - the new forms were thus formally introduced into the official Slovene language, which then became the basis for upcoming school books and, consequently, also ensured the predominance of the new forms, despite opposition from Bleiweis and his periodical, Novice (Breznik 1982: 88). On this page, Breznik also systematically and clearly states the new forms by Svetec, who introduced them in his articles published in 1849 . 
various dilemmas of the Spoken Standard, as well as discussions about the suitability of the base for the Standard Slovene language, are a consequence of the fact that the Spoken Standard language did not have a pressing need to be codified, as it was not present in every official and public position. From Trubar onwards, and later Schönleben, the regional deviations were permitted within the context of Spoken Standard, speaking according to the "customs of the region." Ljubljana linguistically remained torn between literature and regionalism (Tivadar 2010b). Spoken Standard language began to be established as the preferred means of public discourse as late as in the $19^{\text {th }}$ century, featured as a parliamentary language, which was, at the time, defined as a spoken version of the written language (Cegnar in Novice 1861: 199, 396). This was contrary to the Vuk principle, "write as you speak," which held true for Serbian writings. For the Spoken Standard in Slovenia, a principle in opposition to the Vuk principle was accepted at the end of the $19^{\text {th }}$ century.

\section{WRITTEN LANGUAGE AS THE BASIS FOR THE SPOKEN STANDARD SLOVENE}

Cegnar offered a solution to the aforementioned conundrum: "Let us pronounce our language the way we write it." According to his opinion, there is a need to distinctly articulate voices, not like the Carinthians and Carniolans who, "together with other mistakes, eat half of the sounds" (Novice 1861: 199). With this principle, he argued, we would come closer to other Slavic nations. ${ }^{6}$ This was the age of Pan-Slavism and a linguistic union of the Slavic nations and "dialects," therefore M. P. wrote in Novice, that "all of us, with all our might, must pull together on this, so that we might join in with other Slavic nations as quickly as possible." These writers supported the viewpoint that a common "singular dialect for all Slovenia" must be found, and that everyone had to step back from their own dialect, and speak in a literary style acceptable even to the simple farmers of Carinthia and Styria. ${ }^{7}$ This would produce, effectively, a political unification of Slovenes, as well as other and Slavs (Novice 1861: 251), with the unifying element being the Standard Slovene language. Certain problems for the unified literary accent, and the Cegnar principle, were presented by the accentuation and pronunciation of vowels: "Pronounce each vowel audibly with only the compressed syllables gaining an accent" (Novice 1861: 252). ${ }^{8}$

Unclear articulation (or reduction) of vowels, and a large difference between the written and spoken forms of Central Slovene, meant that Central Slovene (Carniolan)

\footnotetext{
${ }^{6}$ Here he gives a perfunctory statement that we must align with Russians not only "in words but also a little bit in the accent" (Novice 1861: 198).

7 "It may be claimed that the current literary language in Carinthia and Styria is, for a simple farmer as well as for the more polite, not only understandable but also pleasant, which can be seen from the fact that wherever in these two lands you arrive and to whomever you speak in the current literary language, they answer with special delight and a certain inborn ability" (Novice 1861: 251).

${ }^{8}$ A more articulated pronunciation was to be closer to most dialects. The compressed syllables are syllables or vowels that were made from several vowels, for example "pojó," instead of "pójejo".
} 
speech did not assert itself as the Spoken Standard. In the $16^{\text {th }}$ century, Ljubljana was not yet a unifying linguistic centre but, due to its interferential central position, where two dialects mixed, it began to function as a unifying locale. The contemporary vocal reduction, typical also for the contemporary speech of residents of Ljubljana, became widespread only in the $17^{\text {th }}$ and $18^{\text {th }}$ century and was, therefore, never included as part of the literary linguistic norm (Orožen 1996: 35, 105, 108; Tivadar 2011: 84-86). That is why attempts by Pohlin and, later, Vodušek and Toporišič, to assert contemporary Ljubljana speech as the Spoken Standard were unsuccessful. Also Škrabec, the socalled father of Slovene phonetics, especially stressed the unreduced pronunciation of vowels within the Slovene spoken standard (Škrabec 1994: 8).

\section{THE UNITY WITHIN DIVERSITY AS A CHARACTERISTIC OF THE SLOVENE SPOKEN STANDARD}

Unification and unity, according to the theory of the Standard language established by the Prague Linguistic Circle, are two of the characteristics of any Standard language. Havránek, in 1969, had this to say on the Standard language: "/S/tandard language is a common way of expressing national community" (Nebeská 1996: 22). Thus, the national component is what is typical of a Standard language and, through this, the Standard language is doomed to various manipulations. Skubic (2003:59) quotes Brozović, who claims that the only two positive attributes of the Standard language are long tradition and a general acceptance.

However, one of the basic functions of a Standard language is that, through general acceptance and permanency (the makings of tradition), uninterrupted public and official functionality is enabled. In the Slovene language, which is regionally/linguistically quite diverse, a general acceptance is all the more important and tradition is, as already mentioned, multi-centennial. Concerning written language, we can speak of a centennial uniformity. As for the spoken language, the Schönleben principle of "regional speech" was, unfortunately, at odds with the unified written language, even in the $20^{\text {th }}$ century. The spoken language is already ontologically subjected to diversity, and to a higher degree of changeability, than the written linguistic code.

Sizeable geographic division is an immanent property of the Slovene language. We divide the Slovene language into seven or eight different dialectal groups, and more than 50 different spoken variants, all with considerable differences, especially in phonetic expression (Logar 1993; Logar et al. 2001). This is reflected also in media speech, where we have approximately $50 \mathrm{TV}$ and 100 radio stations, which is quite a lot for the 2 million speakers of the Slovene language (Tivadar 2006; 2008b). Geographical, linguistic stratification is thus also present in the media. This demands a particular tolerance from linguists, when defining phoneme variants and accent in Spoken Standard (e. g. pronouncing numerals from 12 to 19 as "dvánajst" and "dvanájst", "trínajst" and "trinájst" etc. in SP 2001 and SSKJ; Tivadar/Jurgec 2003). 


\subsection{The Unifying Slovene Written Language}

Writing has been interlaced with public speech for a good century now and has, in a way, established the Spoken Standard. The biggest problem in Slovene linguistics is the non-acceptance of the different roles of these two linguistic codes (written and spoken). The Slovene space has always been quite diverse, when it comes to speech. But, at the same time, the tendency towards the national unification of the language is typical for Slovenia (Tivadar 2012). Spoken Standard language is, thus, conditioned by the written language and, due to the aforementioned geographic stratification, and the differences in the spoken and written languages, certain deviations appear which are, however, quite common in a spoken language. The Spoken Standard language is necessarily tied to the written language, to which it must not be subordinate, at least in the Slovene example. Besides this, contemporary media texts are very much connected to the written code - the most-watched television shows on all Slovene TV stations include the news, which is read, and round table discussions on important informative themes, both of which use the Spoken Standard. Also, politicians in press conferences use, as a rule, the Spoken Standard (Tivadar 2006; 2008b).

Also in the Slovene example, statements by Czech linguists hold true, in the sense that, in speech, it often comes to "mixing" of individual speech types, as with the "obecná čeština" variant of the Czech language, inter-dialect and Standard language, typical of the city speech (Čechová 2000: 25-26). The Czech (phonetically-phonological) normativistism does argue in favour of the basic Czech Spoken Standard language that is spoken in the central Czech Republic, with the exception of Prague and its surroundings. For Moravia, a certain variants are accepted (Palková 1997: 321). Other tendencies are also present in the Czech Republic, tendencies that expose the "obecná čeština" language, or the general conversational language, based on the central-Czech dialect: its use in literature, for example, and with some speakers in public positions, who are in favour of the otherwise Standard language. The "obecná čeština" is, in fact, a symbol of genuine speech, in contrast to the taught Standard, which is the standardised, artificial Czech language that most Czech people would not know how to speak (Čermák 1996: 14-18; on the development and beginnings of the literary Czech and the historical role of "obecná čeština," see cf. Stich 1991).

But the big question is whether, in the third millennium, the regional speech (for example, in the Czech capital of Prague, or in the Slovene capital of Ljubljana) can be the actual basis for the Standard language.

In the Slovene example, we find tendencies (more extensively explained in Tivadar 2010b), such as the centralistic principle of standardisation, which uses both written and centralised views when explaining the definition of Standard Slovene language towards the written and the centralised speech principle:

1. Toporišič, in the only complete Slovene grammar book (first published in 1976), claims that the speaker of Standard Slovene is a "linguistically-trained person (at least to middle school level)." He adds that Standard Slovene " in Slovenia is, first and foremost, the written language" (Toporišič 2000: 15) ${ }^{9}$ 
2. Along with this written description of Standard Slovene, to which Toporišič also attributes a unifying and representative function, he exposes a "trans-Slovenian colloquial" (slov. "splošnopogovorni") language that "more than the Standard Slovene, leans on the regular, everyday, discourse language of non-dialect speaking people all over Slovenia and, especially, in its centre - Ljubljana, and its more or less urbanised wider surroundings" (Toporišič 2000: 18, underlined by H. T.). Toporišič admits that the Spoken Standard language is not generally accepted all across Slovenia: "That which should become truly general (as Standard Slovene is generally accepted and also defended), actually exists in quite a well-formed manner in the central Upper-Lower Carniola area, with a centre in Ljubljana and its surrounding, and, in part, even more-distanced urban settlements" (Toporišič 2000: 17). With the "trans-Slovenian colloquial" language, according to Toporišič, certain social classes ("the educated, especially urban") are already being born, but this is not Slovene language reality. Here, we must put forth the questions regarding the current linguistic situation. Does Ljubljana have a unified linguistic norm? Is it possible that it is an entirely special metropolis, different from Prague, for instance, despite the influences of different dialects, languages, and generations of speakers (Tivadar 2010b: 41-42)?

Why have we exposed these claims by Toporišič? Toporišič and his claims still hold the leading position in Slovenia. ${ }^{10} \mathrm{He}$ wishes to create a Spoken Standard, which is distinctively oriented toward centralisation, has no basis in tradition, and has no general acceptance, all of which he freely admits. That is why he wishes to adapt this primary, "inborn" Spoken Standard language for general use since, according to his opinion, it must be the basis of a Standard language:

[Trans-Slovene colloquial language] becomes even more general if, with a conscious intervention, we undercut the properties that make it more closely provincial.[...] Trans-Slovenian colloquial languages for the Standard Slovene are sort of a preparation, which lead the linguistic assets of geographical dialects and provincial colloquial languages somehow toward the roles of Standard Slovene (Toporišič 2000: 17).

We argued, in several places, (Tivadar/Jurgec 2003; Tivadar 2010a; Tivadar 2010c) against these sorts of violent tensions towards a "natural" base for the Standard language, which is conditioned by region and centrality, seeing as these sort of idealizations in several public discussions, ${ }^{11}$ and in some articles (Toporišič 2003), have turned into an unconstrained search for a perfect speaker from a linguistically very diverse area, such as the Slovene capital. Such attempts can also lead to various forms of societal intolerance. For example, a few years ago, the still-presiding mayor of Ljubljana, who only spent a part of his childhood in Serbia, was accused of being an unnatural

\footnotetext{
${ }^{9}$ He defines literary language from the viewpoint of the creator, a serial addressee, and official status. Besides this he emphasises the educational, social and dialectal inequality, which conditions the use of Standard Slovene (Toporišič 2000: 15).

10 The Concept of Central Slovene speakers as a foundation of the literary form is defended also by some other linguists (Jurgec 2005; 2011).

11 RTV SLO 1, Studio ob sedemnajstih, 20. 5. 2002.
} 
citizen of Ljubljana, for not having been born there, and therefore unable to understand his own city. ${ }^{12}$

Many speakers can feel excluded, especially Slovenes in the neighbouring countries:

Even our language, our Slovene language, is losing its footing in central Slovenia. The language, the only thing that unified us, and that we here, in the times of greatest pressure, have nurtured with love and persistence, seems to be becoming useless to some ... Here we are besieged by the Italian language, on the streets, in offices, and especially on television. How do we feel when we realise how the linguistically-refined speech on Italian television fights with a loose and constantly-enforcing Ljubljana dialect on the central Slovene television? It seems as if we do not need a language to unify us all but, rather, to accentuate the differences that divide us. According to such criteria, everyone will nurture only their own dialect, while we will communicate only in Italian, whereas in central Slovenia, we will communicate only in English (by prof. Nada Pertot from Trieste; Dolgan 1996: 70-71).

Two teachers of rhetoric also contemplate public speaking in Slovenia, when they consider how a Slovene teacher should speak "in a language elevated solely by consistency, understood by every Slovene of the same age. There is no Slovene ethnic uniform. It does not exist. Just as there is no Pan-Slovene spoken language. Television is not Slovene. It is a television using the Ljubljana dialect" (Zupančič/Zupančič 2003: 505).

The Standard Slovene language is unified, while the spoken language is diverse, depending on the spoken discourse. Therefore, we cannot equate the regionallycoloured Spoken language with the Standard language.

Standard Slovene language is tied to the written linguistic code, as shown by the state of contemporary media in Slovenia (cf. Tivadar 2008b; 2011), where it is still predominant in the more content-heavy and demanding RTV shows.

\section{TOPICAL MEDIA SPEECH AND ITS DESCRIPTION, AS PROOF OF A UNI- FIED SPOKEN STANDARD}

Contemporary research, based on researching real contemporary Slovene material (Tivadar 2004b), proves that the Standard Slovene language, including its spoken representation, is suitably unified, and phonetically recognisable, among the speakers of the Slovene language, regardless of their regional origin. Such perceptive tests of minimal pairs prove a large degree of recognisability (between 88 and $100 \%$ ) of phonologically distinctive Slovene vowels - also among the narrow and wide $\langle\mathrm{e}\rangle$ 'pe:t (five) - 'pe:t (G P1 heel) and <o> 'go:st (dense) - 'go:st (guest) (Tivadar 2004b). ${ }^{13}$

We must also emphasise that the vowels of central Slovene, and also non-central Slovene speakers, are entirely comparable when pronounced. We can thus speak of a unified Standard Slovene language (Tivadar 2010a).

12 MMC RTV SLO 2009

${ }^{13}$ In this research (Tivadar 2004b), the typical content distinctive pairs of Slovene vowels were prepared in a neutral sentence position. They were read and spoken by professional radio speakers of Slovene language. 
With regard to comparing Slovene vowels, based on the additional analysis of media speakers (Tivadar 2008a), we discover that, according to gender, the values of individual phonemes, when accounting for the natural deviations, are comparable (see graphs 1 and 2). Therefore, we can claim that, in the field of vowels, the Standard Slovene language is unified, regardless of the origin of the speaker. Dialectal origin does not have a significant influence on the articulation or perception of Standard Slovene vowels.

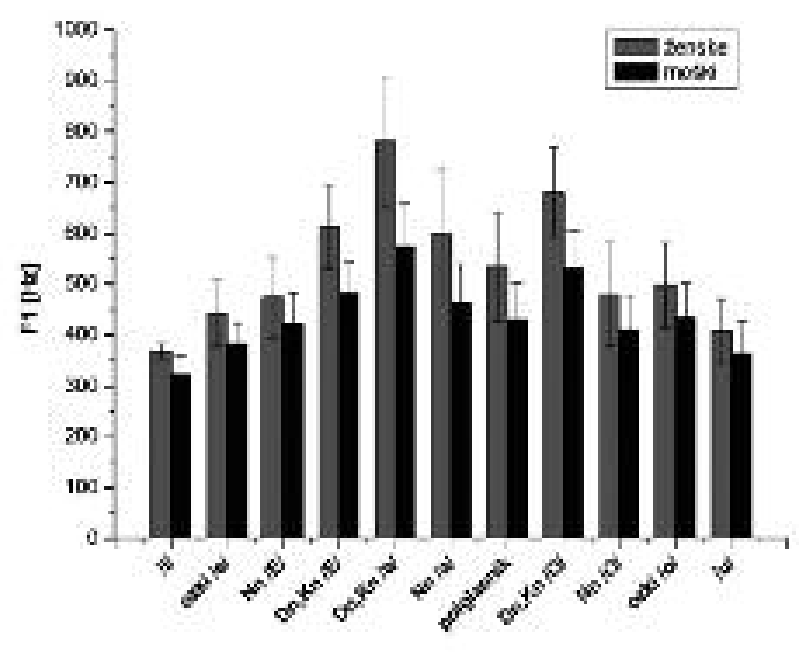

Graph 1: Average values and deviations of the formant F1.

Dn $\neg$ long stressed, Kn - short stressed, Nn - unstressed; ženske - female, moški male, ozki - closed. Polglasnik - semivowel, /E/ - / $/$ /, /O/ - / /. 


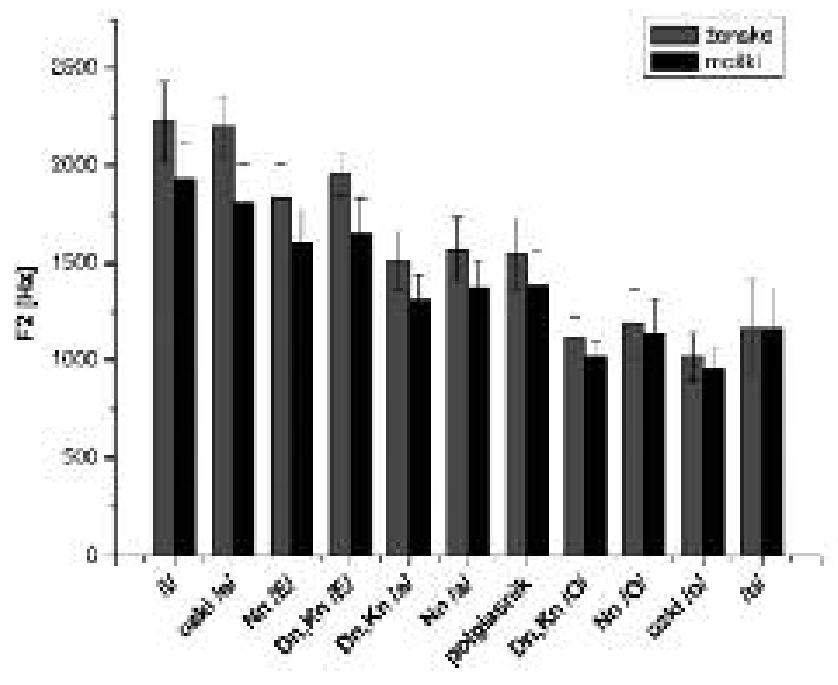

Graph 2: Average values and deviations of the formant F2.

Dn $\neg$ long stressed, Kn - short stressed, Nn - unstressed; ženske - female, moški male, ozki - closed. Polglasnik - semivowel, /E/ - / $\varepsilon /, / \mathrm{O} /$ - / /.

With such a concrete analysis, we can confirm the unified image of the phonetically and dialectally diverse Slovene language. Precisely due to its dialectal diversity, constant adaptation, and the multilingualism of the Slovene territory, its Standard image is, necessarily, speech-tolerant, but tied to the written language.

The pronunciation of vowels in the Slovene language was, in Slovene grammar, often dealt with only in the sense of how one makes a mistake (breaking the rules) or copes with non-central Slovene dialects (e.g., Škofja Loka residents employ short phonemes, Styrian narrow /e/ and /o/ etc.; Toporišič 2000: 50-53, 60). Unfortunately, the regional origin of the speaker as a weakness of the speaker is also exposed in other places (cf. Toporišič 2003: 135).

\section{CONCLUSION}

Creating a new spoken standard on a regional basis, even if based on the speech of the Slovene economic-political-cultural centre (Ljubljana region), would be a step backwards, a walk down the well-trodden path of creating regionally-conditioned standards, which have proved false, and not good for the evolution of Slovene language. Lack of a clearly-articulated contemporary Central Slovene speech, especially regarding vowel sounds, means that Ljubljana regional speech has not asserted itself as the Spoken Standard. Finally, Spoken Standard in the media (and in the public) is in general unified, and is very different from Ljubljana regional speech (cf. Tivadar 2004b; 2006; 2010a). 


\section{References}

BREZNIK, Anton (1982) Jezikoslovne razprave. Ljubljana: Slovenska matica.

ČAR, Janko (1995) "Pravorečje pri Škrabcu, Ruplu in Toporišiču." In: J.Toporišič (ed), Škrabčeva misel 1. Nova Gorica: Franciskanski samostan Kostanjevica, 45-52.

ČERMÁK, František (1996) “Obecná a spisovná čeština: Poměr, funkce a metodologie.” In:

R. S̆ramel (ed), Spisovnost a nespisovnost dnes. Brno: Masarykova univerzita, 14-18.

Dolgan, Marjan (1996) Govorno ustvarjanje. Ljubljana: Rokus.

GJuRIN, Velemir/Jože TopoRišIČ (1993) Slovenska zvrstna besedila. Ljubljana: Filozofska fakulteta.

JESENŠEK, Marko (2010) "Slovenski knjižni jezik med središčem in obrobjem -normativnost in/ali partikularizem.” In: I. Novak Popov (ed), Vloge središča: konvergenca regij in kultur. Ljubljana: Zveza društev Slavistično društvo Slovenije, 13-22.

JURGEC, Peter (2005) "Spet o fonetiki, fonologiji in pravorečju v SP 2001." Slavistična revija 53/2, 245-248.

JURGEC, Peter (2011) "Slovenščina ima 9 samoglasnikov." Slavistična revija 59/3, 243-268.

LogAr, Tine (1993) Slovenska narečja. Ljubljana: Mladinska knjiga.

LoGAR, Tine/Jakob RigLeR/Jerneja FridL (2001) Slovenska narečja. Nacionalni atlas Slovenije. Ljubljana: Rokus.

MMC RTV SLO. 21 September 2011. http://www.rtvslo.si/slovenija/pomladni-podmladki-jankovicu-podarili-monopoli-nato-pa/219780.

NebeSKÁ, Iva (1996) Jazyk, norma, spisovnost. Praha: Univerzita Karlova.

SkUbic, Andrej (2003) "Mesto standardnega jezika v jezikovnem repertoarju posameznika." In: A. Vidovič Muha (ed), Obdobja 20. Ljubljana: Center za slovenščino kot drugi/tuji jezik pri Oddelku za slovenistiko Filozofske fakultete, 209-226.

Slovar slovenskega knjižnega jezika (1991) Ljubljana: DZS.

STich, Aleksandr (1991) "O počátcích moderní spisovné češtiny." Naša Řeč 2, 57-62.

ŠKrabeC, Stanislav (1994) Jezikoslovna dela II. J. Toporišič (ed). Nova Gorica: Frančiškanski samostan Kostanjevica.

TIVADAR, Hotimir (2004a) "Fonetično-fonološke lastnosti samoglasnikov v sodobnem knjižnem jeziku." Slavistična revija 52/1, 31-48.

TIVADAR, Hotimir (2004b) "Priprava, izvedba in pomen perceptivnih testov za fonetično-fonološke raziskave (na primeru analize fonoloških parov)." Jezik in slovstvo 49/2, 17-36.

TIVADAR, Hotimir (2006) "Slovenski medijski govor v 21. stoletju in pravorečje - RTV Slovenija vs.komercialne RTV-postaje/Slovene media speech in $21^{\text {st }}$ century - RTV Slovenija vs. commercial RTV Stations." In: Z. Palková/J. Janoušková (eds), Kapitoly z fonetiky a fonologie slovanských jazyků. Praga: Univerzita Karlova, 209-226.

TIVADAR, Hotimir (2008a) Kakovost in trajanje samoglasnikov v govorjenem knjižnem jeziku. Ljubljana: University of Ljubljana.

Tivadar, Hotimir (2008b) "Pravorečje, knjižni jezik in mediji." In: M. Pezdirc Bartol (ed), Slovenski jezik, literatura, kultura in mediji. 44. seminar slovenskega jezika, literature in kulture. Ljubljana: Center za slovenščino kot drugi/tuji jezik pri Oddelku za slovenistiko Filozofske fakultete, 24-35. 
TivadAR, Hotimir (2010a) "Normativni vidik slovenščine v 3. tisočletju - knjižna slovenščina med realnostjo in idealnostjo." Slavistična revija 58/1, 105-116.

TivadAR, Hotimir (2010b) "Slovenski jezik med knjigo in Ljubljano." In: I. Novak Popov (ed), Vloge središča: konvergenca regij in kultur. Zbornik Slavističnega društva Slovenije 21. Ljubljana: Zveza društev Slavistično društvo Slovenije, 25-35.

TivadAR, Hotimir (2010c) "Gradivna utemeljenost opisa slovenskega (knjižnega) jezika.” In: V. Gorjanc/A. Žele (eds) Izzivi sodobnega jezikoslovja.Ljubljana: Filozofska fakulteta, 53-62.

TIVADAR, Hotimir (2011) "Regionalna (in socialna) različnost slovenskega (knjižnega) jezika v zgodovini in sedanjosti." In: M. Jesenšek (ed), Globinska moč besede: red. prof. dr. Martini Orožen ob 80-letnici. Ljubljana/Maribor: Filozofska fakulteta, 80-91.

TIVADAR, Hotimir (2012) "Nevarna razmerja med pisnim in govorjenim jezikom." In: H. Dobrovoljc/N. Jakop (eds), Pravopisna stikanja - razprave o pravopisnih vprašanjih. Ljubljana: ZRC Sazu, 15-23.

TivaDAR, Hotimir/Peter JURGEC (2003) "Podoba govorjenega slovenskega knjižnega jezika v Slovenskem pravopisu 2001.” Slavistična revija 51/2, 203-220.

TOPORIšIČ, Jože (1976) Slovenska slovnica. Maribor: Založba Obzorja.

TOPORIšIČ, Jože (1992) Enciklopedija slovenskega jezika. Ljubljana: Cankarjeva založba.

TOPORIŠıč, Jože (2000) Slovenska slovnica. Maribor: Založba Obzorja.

ToporišIČ, Jože (2001) Slovenski pravopis. Ljubljana: Založba ZRC Sazu.

TOPORIŠIČ, Jože (2003) "Eksperimentalnofonetične raziskave slovenskega knjižnojezikovnega glasovja in tonemskosti." Slavistična revija 51, 119-140.

VodušEK, Božo (1950) "Pripombe k slovenskemu pravopisu." Novi svet 5/2, 947-954, 1045-1052, 1149-1152.

VodUŠEK, Božo (1959) "Historična pisava in historična izreka." Jezik in slovstvo 4/7, 193-200.

ZUPANČIČ, Zdravko/Ana Aleksandra ZUPANČIČ (2004) "Učitelj - javni govorec/Teacher - public speaker." Govor 20/1-2, 497-51.

\section{Abstract \\ CODIFICATION OF THE SPOKEN LANGUAGE: EXAMPLE OF CONTEMPORARY SLOVENE}

The Slovene language is often presented as a national element. Even in the $19^{\text {th }}$ century, which saw the Spring of Nations and the United Slovenia project, the Slovene language was a constitutive element of the Slovene nation. In the meantime, the Slovene language was positioning itself as an all-Slovene language, trying to be supra-regional.

By the end of the $19^{\text {th }}$ and early $20^{\text {th }}$ centuries, the Slovene written language had stabilized, while at the same time the spoken language had only begun to assert itself. During this time, the prevailing principle was to "speak the way the language is written." In the mid- $20^{\text {th }}$ century, the theoretical idea of a literary language that is based on the central Slovene-speech (i.e. the speech of Ljubljana) came to dominate. In the third millennium, the question is whether a regionally-defined speech can be used as the basis for a Standard language. Another central ques- 
tion is what this "suitable" regionally-conditioned speech would be like. The principle of how important, decision-wise, the centre of a nation is, when it comes to questions of linguistic norms, may seem very attractive and, to a certain extent, logical. However, even examples of historically and linguistically comparable languages do not support the theory of creating the norm for the Standard Slovene language, based on the contemporary speech of Ljubljana, as claimed by Toporišič in Slovenska slovnica and, later, in Slovenski pravopis. Within Slovenia, the Standard Slovene language is tied to written language, which has proven, in the past, to be a suitable way of setting the norm. Regressing back to the principles of standardising a language, based on regional variants, would be unproductive, would introduce needless discord, and would cause problems with everyday, public communication. Contemporary research of actual speech, a portion of which is also presented within this article, confirms the all-Slovene and regionally-independent character of the Slovene Standard language.

Keywords: standard language, standard spoken Slovene, phonetics, Slovene language history, codification, modern language.

\section{Povzetek \\ KODIFIKACIJA GOVORJENEGA JEZIKA: PRIMER SODOBNE SLOVENŠČINE}

Slovenski knjižni jezik je pogosto omenjan kot narodotvorna prvina. Tudi v 19. stoletju (pomlad narodov in program Zedinjena Slovenija) je bila slovenščina konstitutivni element slovenskega naroda. V tem času se je slovenščina uveljavljala kot vseslovenski jezik, ki je hotel preseči regionalne okvire. Konec 19. in v začetku 20. stoletja se je pisna podoba slovenskega jezika ustalila, medtem ko se je kodifikacija govorjenega jezika v tem času šele začela razvijati. Od načela "govori, kot je zapisano" je sredi 20. stoletja prevladala teoretična misel o jezikovnem standardu, ki sloni na osrednjeslovenskem govoru, tj. govoru Ljubljane. V tretjem tisočletju pa se postavlja vprašanje, ali je regionalno utemeljen govor lahko dejanska podlaga knjižnemu jeziku. Poleg tega ni povsem jasno, kakšne lastnosti naj bi ta "ustrezni” regionalno pogojen govor imel. Načelo odločevalnosti nacionalnega centra je pri vprašanjih jezikovne norme sicer dovolj privlačno in do neke mere logično. Toda primeri slovenščini kulturnozgodovinsko in jezikovno podobnih jezikov ne podpirajo teorije normiranja govorjene slovenščine na osnovi centralnega govora, ki jo zagovarja Toporišič v Slovenski slovnici in nadaljuje v Slovenskem pravopisu. Govorni standard je namreč v slovenskem kulturnem prostoru izrazito vezan tudi na pisni jezikovni izraz, kar se je v preteklosti izkazalo za ustrezen način normiranja in poenotenja slovenščine.

Članek predstavi raziskavo sodobnega govora, ki potrjuje vseslovenski in regionalno neodvisni značaj slovenskega standardnega jezika. Zato se zdi, da bi bilo vračanje k principom normiranja jezika na osnovi regionalnih različic neproduktivno, saj bi vnašalo nepotrebno neenotnost in povzročalo težave tudi pri vsakdanjem (javnem) sporazumevanju.

Ključne besede: knjižni jezik, govorni standard, fonetika, zgodovina slovenskega jezika, kodifikacija, sodobni jezik. 